\title{
Pelatihan Asertivitas Untuk Peningkatan Kemampuan Pemecahan Masalah Interpersonal Pada Suami atau Istri Dalam Keluarga Luas (Extended Family)
}

\author{
Wiwin Narti \\ Institut Agama Islam Yasni Bungo \\ Email: wiwinnartimpsi@gmail.com
}

\begin{abstract}
This study aims to determine the effect of assertiveness training to improve the ability to solve interpersonal problems in husband or wife in extended families (extended family). Data analysis using non-parametric Mann Whitney U Test statistics is by looking at the Gained Score obtained from the pretest and posttest scores. Different test results at the pretest and posttest showed a $\mathrm{Z}$ coefficient of $2,956 \mathrm{p}<0.005$. This shows that there are differences in interpersonal problem solving abilities between the experimental group and the control group after giving treatment, where the experimental group has a higher interpersonal problem solving ability (mean rank $=12.00$ ) compared to the control group (mean rank $=5.00$ ) . Furthermore, the Wilcoxon difference test on the pretest and posttest scores in the experimental group at the $Z$ coefficient of $-2,527, p<0.005$, this shows that there is a difference in problem solving ability between the pretest and posttest phases in the $\mathrm{KE}$, where in the posttest phase (mean score $=117,250$ ) husband and wife experienced an increase in interpersonal problem solving abilities compared to the pretest phase $($ mean score $=101,500)$. This indicates that a husband and wife who received assertiveness training experienced an increase in their ability to solve interpersonal problems compared to those who did not receive assertiveness training. Wilcoxon different test results on posttest and follow-up scores in the experimental group showed a $\mathrm{Z}$ coefficient of $-2.103, \mathrm{p}<0.05$. This indicates that there are differences in interpersonal problem solving abilities between after assertiveness training (posttest) and two weeks thereafter (follow-up), in the follow-up phase (mean score $=123.875$ ) the husband or wife again experiences an increase in interpersonal problem solving abilities compared in the posttest phase (mean score $=$ 117,250). This means that assertiveness training has a significant influence on interpersonal problem solving abilities.
\end{abstract}

Keywords: Assertiveness training, interpersonal problem solving skills, husband and wife, extended family

Nur El-Islam, Volume 6, Nomor 2, Oktober 2019 


\begin{abstract}
Abstrak
Penelitian ini bertujuan untuk mengetahui pengaruh pelatihan asertivitas untuk meingkatkan kemampuan pemecahan masalah interpersonal pada suami atau istri dalam keluarga luas (extended family). Analisis data menggunakan statistik nonparametrik Mann Whitney U Test yaitu dengan melihat Gained Score (skor selisih) yang diperoleh dari skor pretest dan posttest. Hasil uji beda pada pretes dan posttest menunjukkan koefisien Z sebesar $-2.956 \mathrm{p}<0,005$. Hal ini menunjukkan bahwa ada perbedaan kemampuan pemecahan masalah interpersonal antara kelompok eksperimen dan kelompok kontrol setelah pemberian perlakuan, dimana kelompok eksperimen memiliki kemampuan pemecahan masalah interpersonal lebih tinggi (mean rank $=12,00)$ dibandingkan dengan kelompok kontrol (mean rank $=5,00$ ). Selanjutnya, uji beda Wilcoxon terhadap skor pretest dan posttest pada kelompok eksperimen pada koefisien $\mathrm{Z}$ sebesar $-2,527, \mathrm{p}<0,005$, hal ini menunjukkan bahwa ada perbedaan kemampuan pemecahan masalah antara fase pretest dan fase posttest pada KE, dimana pada fase posttest (mean score $=117,250$ ) suami-istri mengalami peningkatan kemampuan pemecahan masalah interpersonal dibandingkan dengan fase pretest (mean skor $=101,500)$. Ini menandakan bahwa suami-istri yang mendapatkan pelatihan asertivitas mengalamai peningkatan kemampuan pemecahan masalah interpesonal dibandingkan suami-istri yang tidak mendapatkan pelatihan asertivitas. Hasil uji beda Wilcoxon terhadap skor posttest dan follow up pada kelompok eksperimen menunjukkan koefisien $\mathrm{Z}$ sebesar -2,103, p<0,05. Hal ini menandakan bahwa ada perbedaan kemampuan pemecahan masalah interpersonal antara setelah pelatihan asertivitas (post test) dan dua minggu setelahnya (follow-up), pada fase follow-up (mean score $=123,875$ ) suami atau istri tersebut kembali mengalami peningkatan kemampuan pemecahan masalah interpersonal dibandingkan pada fase posttest (mean score $=117,250$ ). Ini berarti bahwa pelatihan asertivitas memiliki pengaruh berarti terhadap kemampuan pemecahan masalah interpersonal.
\end{abstract}

Kata Kunci: Pelatihan asertivitas, kemampuan pemecahan masalah interpersonal, suami-istri, keluarga luas (extended family)

\title{
A. Pendahuluan
}

Setiap suami atau istri mendambakan sebuah pernikahan yang langgeng dan hanya sekali untuk seumur hidup, namun keharmonisan tidak selalu bisa diraih, hal ini terlihat dengan angka perceraian yang setiap tahunnya terus menunjukkan peningkatan. Rapuhnya tumah tangga justru banyak terjadi pada pernikahan usia muda. Menurut Kementrian Agama tahun 2010, 80\% kasus perceraian terjadi pada usia pernikahan di bawah lima tahun. Dirjen Bimas Islam dan Urusan Haji 
Kementerian Agama mengatakan bahwa kasus perceraian untuk usia pernikahan enam tahun ke atas justru cukup rendah. ${ }^{1}$

Pada tahun 2005 kasus perceraian mencapai rata-rata 50.000 pernikahan per tahun. Kemudian data tahun 2010 menunjukkan bahwa perceraiana terjadi pada 200.000 pernikahan tiap tahunnya. Angka tersebut tergolong cukup besar karena mencapai sekitar 10 persen dari jumlah pencatatan pernikahan. Demikian juga dengan jumlah cerai gugat terus meningkat. Lima hingga sepuluh tahun lalu, kasus istri menggugat cerai suami hanya 10-20 persen, namun di tahun 2010 tiga perempat dari perceraian adalah karena istri menceraikan suami. ${ }^{2}$

Untuk Kabupaten Wonosobo, kasus perceraian sebelum 2010 lalu cukup tinggi. Selama setahun jumlah perkara cerai yang diterima Pengadilan Agama Kelas 1 A Wonosobo mencapai 2.206. Rinciannya, 855 kasus adalah cerai talak atau perkara cerai yang diajukan oleh pihak laki-laki, sedangkan cerai gugat atau perkara yang diajukan pihak perempuan sebanyak 1.351 kasus. Dibandingkan tahun 2009, jumlah kasus ceria yang diterima Pengadilan Agama Wonosobo pada tahun 2010 meningkat. Tahun 2009, perkara cerai yang diterima sebanyak 2.143 kasus, dengan rincian 871 kasus cerai talak dan 1.272 kasus cerai gugat. Perceraian merupakan keputusan yang paling tidak diinginkan oleh siapa pun. Untuk mencegah perceraian, ada baiknya diketahui dan dikenali akar permasalahan yang mungkin menjadi bibit perceraian tersebut. Ada berbagai alasan dan sebab perceraian yang diajukan oleh masyaraakt khususnya suami atau istri ke pengadilan, pada umumnya antara satu alasan perceraian dengan alasan lainnya hampir selalu berkaitan, salah satu diantaranya adalah adanya pihak ketiga dalam rumah tangga. ${ }^{3}$

Pihak ketiga dalam rumah tangga bisa berasal dari keluarga ataupun orang lain yang serumah. Tidak sedikit suami atau istri yang karena suatu alasan tertentu harus tinggal seatap bersama orang tua

${ }^{1}$ Umar, N. Perceraian Usia Muda. POSMETRO. 14 September 2010.

${ }^{2}$ Ibid.

3 Daromi, F. Membina keluarga dengan mengenali bibit. http://arsinfo.co.cc/2010//11/.html. Diakses 11 April 2019. 
atau mertua, bahkan ada pula yang berserta saudara kandung dan iparnya. Kebersamaan dalam satu atap dapat berpotensi memunculnya berbagai masalah keluarga, misalnya adanya ketidakmampuan beradaptasi, kebiasaan, pola hidup antara satu keluarga inti dengan keluarga lain, atau antara menantu dengan mertua dan kesulitan memilih siapa yang harus dibela dan diutamakan ketika terjadi perselisihan antara orang tua kandung dengan istri atau suami.

Selain itu, permasalahan juga dapat terjadi dalam pengelolaan keuangan keluarga, walaupun biasanya pemilik rumah tempat tinggal yang mengendalikan keuangan. Namun karena sesuatu alasan sumber keuangan bisa tidak berasal dari pemilik rumah, misalnya anak memberi uang belanja yang nilainya besar kepada orangtua selaku pemilik rumah namun setelah dibelanjakan tidak sesuai dengan makanan dan minuman yang dihidangkan atau bisa juga uang belanja berasal dari salah satu keluarga inti yang dianggap lebih mapan dibandingkan keluarga inti lainnya. Hal ini dapat memicu keinginan untuk berpisah dari rumah orang tua atau mertua untuk menyelesaikan masalah, namun suami atau istri yang merupakan anak kandung menolak untuk berpisah karena merasa harus patuh pada orang tua dan lain-lain. Kemudian akhirnya salah seorang memutuskan meninggalkan suami atau istrinya untuk berpisah hidup. ${ }^{4}$

Senada dengan pendapat di atas, Solikah menyatakan bahwa dalam satu rumah yang terdapat beberapa kepala keluarga dapat memicu terjadinya konflik antar anggota keluarga yang memaksa untuk tidak saling sapa, saling menjelekkan, dan bahkan saling mencari kesalahan orang lain serta semakin membenarkan dirinya sendiri. Hal ini biasanya diakhiri dengan saling berebut perhatian dan dukungan pihak orang tua, baik orang tua kandung atau mertua. Persaingan perolehan materi di antara keluarga yang berseteru akan semakin meningkat kadar kebencian diantara anggota keluarga. Banyaknya anggota keluarga besar ini, sering sekali memunculkan adanya konflik-konflik, karena terdapat perbedaan usia, minat,

\section{${ }^{4}$ Ibid}


kebiasaan, sikap, gaya hidup, status sosial ekonomi, cara mendidik anak dan lain sebagainya. ${ }^{5}$

Hardjono menguatkan, konflik interpersonal dengan saudara ipar atau dengan suami, atau istri dari saudara ipar yang tinggal dalam keluarga besar juga tidak kalah sering terjadi. Jika tidak segera disadari dan diambil tindakan nyata, cepat atau lambat permasalahan ini tentu akan memiliki dampak negatif. Kondisi keluarga luas seperti di atas yang sarat akan konflik, menuntut suami atau istri dalam keluarga luas untuk memiliki kemampuan pemecahan masalah interpersonal (interpersonal problem solving) yang baik atau tinggi. ${ }^{6}$ Sesuai dengan pendapat Covey yang menyatakan bahwa tuntutan akan pemecahan masalah adalah kunci untuk keberlangsungan keluarga. ${ }^{7}$ Menurut Levine, permasalahan yang dihadapi individu pada dasarnya terdiri dari dua macam yaitu permasalahan intelektual dan permasalahan interpersonal. Permasalahan interpersonal adalah permasalahan yang terjadi antar individu. ${ }^{8}$

Pemecahan masalah interpersonal merupakan usaha yang dilakukan dengan mempertimbangkan kebutuhan-kebutuhan, tindakan-tindakan, atau hak-hak individu lain dalam memecahkan masalah dan melibatkan strategi yang digunakan (misalnya menggunakan kontak mata, melihat dari berbagai sudut pandang) dan pada proses mental yang turut mewarnai dalam pemecahan masalah. Pemecahan masalah interpersonal yang baik didasarkan pada prinsip yang menunjukkan bahwa masing-masing pihak yang bertikai memiliki sikap mental yang positif, maka akan ada berbagai macam kemungkinan, mulai dari berbicara dengan pihak lain, menemukan kompromi, melakukan penyesuaian dan mencari bantuan. ${ }^{9}$

${ }^{5}$ Solikah. Konflik interpersonal antara anggota keluarga besar. Skirpsi. Tidak diterbitkan: Fakultas Psikologi Universitas Muhammadiyah Surakarta. 2010.

${ }^{6}$ Hadjono. Perlakuan salah di dalam keluarga. Laporan Seminar. Fakultas Kedokteran Universitas Udayana Denpasar. 1985.

${ }^{7}$ Covey. Principle-centered leadership. Simon \& Schuster, London. Buletin Psikologi. Tahun IX, No. 2, Desember 2001. h. 39-40.

${ }^{8}$ Levine, Effective problem solving. (New Jersey: Prentice Hall Inc. 1998.)

${ }^{9}$ Ibid. 
Menurut Thurstone, individu dalam mengartikan suatu masalah akan bersikap positif bila masalah tersebut menimbulkan perasaan senang, sehingga individu menerima, tetapi dapat pula bersikap negatif bila masalah tersebut menimbulkan perasaan tidak enak sehingga individu menolak. ${ }^{10}$ Anderson mengatakan bahwa individu yang dikategorikan sebagai pemecah masalah yang buruk apabila cenderung menemukan masalah dengan sikap tidak senang, sering merasa terancam, dan cenderung menghindar untuk memikirkan masalah. ${ }^{11}$

Kemampuan untuk memecahkan masalah interpersonal merupakan faktor penting untuk menentukan penyesuaian individu. ${ }^{12}$ Individu yang memiliki kemampuan pemecahan masalah interpersonal yang baik dan tinggi dapat ditunjukkan dengan sikap mental yang positif dalam pemecahan masalah, meliputi: memusatkan perhatian pada apa yang dapat dilakukan untuk mengubah atau memperbaiki situasi dan bagaimana cara terbaik untuk mencapai perubahan tersebut tanpa melanggar hak-hak orang lain; cara bicara yang baik, meliputi: mengatur kontak mata dan nada suara proporsional, sopan, mengatur humor, dan ketenangan emosi. Selain itu mampu memediasi permasalahan pihak lain, meliputi: tidak menghakimi (tidak memilih benar dan salah), menghindari prasangka, tidak mengarahkan, mendorong kedua belah pihak pada solusi uang realistis, memberi kesempatan kedua belah pihak untuk "terbuka", atau mengeskpresikan kemarahan, untuk melepaskan frustrasinya, menjadi lebih menerima untuk melakukan negosiasi, dan melihat dari berbagai sudut pandang. ${ }^{13}$

Pada kenyataannya, berdasarkan wawancara yang dilakukan peneliti dari tanggal 15 september - 10 Desember 2010, terhadap 10 orang suami istri dalam keluarga luas di Wonosobo, menunjukkan bahwa suami istri tersebut kurang mampu mengatasi masalah

${ }^{10}$ Bimo Walgito. Psikologi Sosial. (Yogyakarta: Andi Offset. 2003.)

${ }^{11}$ Anderson B.F. The complete thinker. A hand book if techniques for creative and critical problem solving. (Englewood Clift, New Jersey: Prentice-Hall Inc. 1980)

${ }^{12}$ Spivack, Platt, \& Shure. The problem-solving approach to solving real life problem. (San Franssisco: Jossey-Bass. 1976)

${ }^{13}$ Levine. Effective problem solving, 
interpersonal dengan baik, sering kali keputusan yang diambil merupakan keputusan yang tidak tepat, tidak mampu mengubah keadaan yang semestinya masih bisa untuk diubah, cenderung pasif atau berdiam diri yang pada akhirnya menggunakan amarah, dan kekerasan verbal maupun non verbal ketika masalah tersebut sudah sulit untuk dibendung, tidak mampu memediasi permasalahan antara suami atau istrinya dengan orang tua kandung, hal ini menandakan bahwa suami-istri tersebut tidak memiliki sikap mental dan cara bicara yang baik dalam pemecahan masalah interpersonal dan kesulitan untuk memediasi suami atau istri dengan orang tua kandung yang bertikai.

Ada beberapa faktor yang mempengaruhi kemampuan pemecahan masalah interpersonal yaitu usia, kepercayaan diri, motivasi, kebiasaan, dukungan sosial dan komunikasi. Penelitian ini menyoroti komunikasi sebagai faktor yang mempengaruhi kemampuan pemecahan masalah interpersonal. Menurut Myers \& Myers, lima gaya individu dalam gaya individu dalam berkomunikasi, antara lain: gaya mencela atau agresivitas, gaya menenangkan atau nonasertif, gaya intelektual, dan gaya pengaturan atau asertivitas. Peneliti menyoroti pengaruh komunikasi khususnya gaya asertivitas karena gaya asertivitas lebih kontruktif dibandingkan gaya komunikasi lainnya. ${ }^{14}$

Asertivitas dapat membantu peningkatan rasa percaya diri, penghormatan diri, dan rasa hormat terhadap orang lain. Asertivitas merupakan memampuan untuk menegakkan hak-hak pribadi dan mengekspresikan perasaan, pikiran, dan kebutuhan secara langsung, jujur, dan terus terang. Asertivitas berarti menghormati diri sendiri tetapi juga menghormati orang lain, dan mencari kesepakatan dan bernegosiasi secara terbuka. Sasaran asertivitas adalah komunikasi dan pemecahan masalah interpersonal dengan mutualitas yang lebih baik. ${ }^{15}$

${ }^{14}$ Myers \& Myers. The dynamic of human communication: A Laboratory Approach. Sixt Editon. (Singapore: Mc.Graw Hill.Inc.1992.)

${ }^{15}$ Ibid. 
Menurut Kelley, asertivitas merupakan sikap seseorang dalam mengeskpresikan dirinya dengan landasan hak pribadinya sendiri tanpa menyakiti dan menyinggung hak pribadi orang lain. ${ }^{16}$ Neilage \& Adam dalam Syukri \& Zulkarnain menyatakan bahwa asertivitas merupakan proses untuk menghilangkan hambatan personal dalam memecahkan masalah. ${ }^{17}$ Menurut Kanfer \& Goldstein, individu asertif dapat membela diri ketika diperlakukan tidak adil, mampu memberi tanggapan terhadap masalahnya dan mampu menyatakan cintanya. ${ }^{18}$ Menurut Rees \& Graham, asertivitas dapat dilatih dan dikembangkan melalui pelatihan asertivitas yang mengajarkan memilih kata-kata yang tepat untuk tujuan yang diinginkan, saling mendukung, dan pengulangan asertivitas dalam berbagai situasi. ${ }^{19}$

Asertivitas merupakan salah sau keterampilan sosial yang penting artinya dalam menjalin komunikasi interpersonal secara efektif dan kemampuan ini lebih merupakan suatu yang dipelajari dalam perkembangan individu. Seseorang memiliki kecenderungan perilaku pasif, agresif, atau asertif, bahkan manipulatif bukanlah perilaku bawaan tetapi merupakan pola perilaku yang sebagian besar dipelajari dalam lingkungan sosialnya. ${ }^{20}$ Dalam penelitian ini asertivitas dikembangkan melalui metode pelatihan.

Menurut Thanan, metode pelatihan saat ini menjadi sarana pendidikan yang penting, karena pendidikan tidaklah cukup dengan mengubah pengetahuan semata, melainkan juga harus mengubah aspek lain, seperti: keterampilan, keyakinan, orientasi serta pengalaman dengan mengubah metode, suasana, dan waktu. ${ }^{21}$ Goldstein menambahkan bahwa pelatihan merupakan salah satu

${ }^{16}$ Kelley, Harold H. Attribution Theory in Social Psychology. Nebraska Symposium on Motivation, Vol 15, 1967, h. 192-238.

${ }^{17}$ Syukri \& Zulkarnain. Asertivitas dan kreativitas pada karyawan yang bekerja di multi level marketing. Jurnal Psikologia. Vol. I, No.2, 46 - 51. 2005.

${ }^{18}$ Kanfer, F. H. \& Goldstein, A. P. Helping people change. (New York: Pergumon press. 1986.)

${ }^{19}$ Rees, S \& Graham, R.S. Assertion training: how to be who you really are. (Strategies for mental health). (New York : A Tavistock/Routledge Publication. 1991)

${ }^{20}$ Burley-Allen. Managing assertively-how to improve your people skills. (New York: John Wiley and Son.Inc. 1983.)

${ }^{21}$ Thanan. Risalah pergerakan pemuda Islam. (Jakarta: Visi Media. 2001) 
metode yang banyak digunakan untuk mengajarkan perilaku-perilaku baru maupun memperbarui perilaku-perilaku yang selama ini sudah dimiliki, termasuk keterampilan asertivitas. Pembelajaran dikatakan aktif karena mencakup tidak hanya aktivitas pikir (kognitif atau intelektual), tetapi juga perilaku emosi, sosial, fisik, dan spiritual. Dengan demikian proses ini akan bermuara pada peningkatan kemampuan merasakan, menyadari, dan bertindak.

Pelatihan asertivitas dalam penelitian ini merupakan program yang disusun dalam bentuk pelatihan yang diberikan kepada suami atau istri dalam keluarga luas yang memiliki kemampuan pemecahan masalah interpersonal rendah hingga sedang. Pelatihan dibagi dalam sembilan sesi, dengan materi yang mengacu pada aspek-aspek asertivitas berdasarkan teori Myers \& Myers $^{22}$ dan Lazarus dalam Walker dkk, ${ }^{23}$ yang juga digunakan pada penelitian yang dilakukan oleh Uyun, ${ }^{24}$ aspek-aspek tersebut terdiri dari: (1) meningkatkan kesetaraan hubungan, (2) membangun kesadaran diri, (3) mengekspresikan pikiran dan perasaan, (4) mampu menerapkan hakhak pribadi, (5) saling memberi salam, (6) berbagi perasaan, (7) memberi dan menerima bantuan, dan (8) mengatasi kejengkelan dan amarah.

pelatihan asertivitas dapat meningkatkan kualitas suatu hubungan, melalui pelatihan seseorang yang memiliki pengalaman bersosialisasi yang kurang menyenangkan dapat belajar untuk menganalisa situasi yang sulit dihadapi, menggabungkan informasi, menggali keinginan dan tujuan diri dan kemudian mengkomunikasikannya secara efektif. ${ }^{25}$ Selain itu, pelatihan asertivitas mengajarkan keterampilan-keterampilan verbal dan non verbal untuk mengatasi situasi-situasi tidak nyaman berupa

${ }^{22}$ Myers \& Myers. The dynamic of human.

${ }^{23}$ Walker, et.all. Clinical procedures for behavior therapy. (New Jersey: PrenticeHall.Inc. Englewood Cliffs.)

${ }^{24}$ Uyun. Pelatihan asertivitas untuk meningkatkan ketahanan istri. Fenomena: Vol. 2, No.1, Maret 2004.

${ }^{25}$ Soresi, S., Nota, L., dan Robert,W. Relation of Type and Amount of Training to Career Counseling Self-Efficacy in Italy. The Career Development Quarterly, Vol. 52,No 3, ProQuest Research Library, pg. 194. 2004 
menyalahkan diri sendiri, pasif atau agresif. ${ }^{26}$ Ismayudha menambahkan bahwa dalam penelitian asertivitas mengajarkan memilih kalimat untuk beberapa situasi seperti kata "maaf" di awal, menyatakan perasaan dan keputusan yang sebenarnya, menyatakan alasan yang mendasari dan memberi alternatif pemecahan masalah. ${ }^{27}$ Oleh karena itu peneliti berasumsi bahwa pelatihan asertivitas dapat mempengaruhi kemampuan pemecahan masalah interpersonal suami atau istri dalam keluarga luas yang sarat akan konflik.

Berdasarkan hasil penelitian Farida menemukan bahwa penelitian asertivitas sangat efektif untuk meningkatkan kemampuan pemecahan masalah. ${ }^{28}$ Dapat disimpulkan bahwa dengan diberikan pelatihan asertivitas maka kemampuan pemecahan masalah suami atau istri dalam keluarga luas akan meningkat, terutama pada permasalahan interpersonal. Suami atau istri dalam keluarga luas yang mendapatkan pelatihan asertivitas akan memiliki sikap mental yang baik yaitu mempunyai keberanian untuk berbicara dan memulai pembicaraan dengan orang lain, mencari dukungan, untuk beradaptasi, mencari bantuan, dan untuk bertindak. Setelah memiliki sikap mental, melalui pelatihan ini suami atau istri mengerti cara berbicara dengan baik yaitu dengan mengekspresikan diri dengan menggunakan kontak mata dan suara yang prorporsional, berbicara, menggunakan cara-cara yang sopan, humor, dan emosi yang tenang karena suami atau istri tersebut tidak mudah tersinggung dan mempelajari bagaimana merespon hinaan dari orang-orang sekitar. ${ }^{29}$

Kemudian, suami atau istri yang mendapatkan pelatihan asertivitas mampu untuk memediasi permasalahan, contohnya dalam keluarga luas, posisi suami atau istri sering terjebak dalam konflik yang terjadi antara orang tua kandung dengan pasangannya, yang bersangkutan tidak mengetahui bagaimana menjadi mediator yang

\footnotetext{
${ }^{26}$ Bower, Gordon H., Theories Of Learning, (Englewood Cliff : Prentice Hall,1981)

${ }^{27}$ Ismayudha, Y. Pengaruh pelatihan asertif terhadap kecemasan sosial pada remaja. (Skripsi. Yogyakarta: Universitas Gadjah Mada. 1995).

28 Farida. Efektivitas pelatihan asertivitas untuk meningkatkan kemampuan pemecahan masalah pada siswa. (Tesis. Yogyakarta: Program Pascasarjana Universitas Gadjah Mada. 2006).

${ }^{29}$ Levine. Effective problem solving,
} 
baik karena individu yang asertif adalah individu yang tegas, objektif, atau realistis, tidak menyangkal hak-hak orang lain, mampu berempati, adil, mampu mengkomunikasikan pikiran dan ide dengan baik. ${ }^{30}$

\section{HIPOTESIS}

Suami atau istri yang mendapatkan pelatihan asertivitas memiliki kemampuan pemecahan masalah yang lebih tinggi dibandingkan dengan suami atau istri yang tidak mendapatkan pelatihan asertivitas.

\section{B. METODOLOGI PENELITIAN}

\section{Variabel Penelitian}

Variabel-variabel dalam penelitian ini adalah kemampuan pemecahan masalah interpersonal sebagai variabel tergantung dan pelatihan asertivitas sebagai variabel bebas. Definisi operasional dari varibel-variabel tersebut adalah sebagai berikut: pertama, kemampuan pemecahan masalah interpersonal merupakan usaha yang dilakukan individu dalam memecahkan masalah interpersonal dengan mempertimbangkan kebutuhan-kebutuhan, tindakan-tindakan, atau hak-hak individu lain dimana strategi yang digunakan seperti cara bicara, proses mental dan mediasi turut mewarnai dalam pemecahan masalah tersebut. Kemampuan pemecahan masalah interpersonal diukur melalui Skala Kemampuan Pemecahan Masalah Interpersonal. Kedua, pelatihan asertivitas yaitu serangkaian metode pengembangan keterampilan asetivitas yang disusun secara sistematis berupa rangkuman dari konsep, sikap dan keterampilan yang dipelajari dan dikembangkan untuk melakukan modifikasi perilaku dari individu yang non asertif menjadi individu yang asertif.

\section{Desain Eksperimen}

Penelitian ini merupakan penelitian kuantitatif dengan pendekatan eksperimen yakni memberikan suatu perlakuan berupa pelatihan asertivitas. Rancangan eksperimen yang digunakan adalah

${ }^{30}$ Ibid 
pretest-posttest control group design. Desain tersebut digunakan karena dalam penelitian ini efek suatu perlakuan terhadap variabel tergantung diuji dengan cara membandingkan keadaan kelompok eksperimen sebelum dan setelah dikenai perlakuan, dengan kelompok kontrol yang tidak diberi perlakuan. Kelompok eksperimen adalah kelompok yang diberikan perlakuan. Kelompok kontrol yaitu kelompok yang tidak diberi perlakuan. Bentuk rancangan pretestposttest control group design tersebut sebagai berikut:

Gambar 1

Bagan Rancangan Eksperimen

\begin{tabular}{llllll}
\hline & $\mathrm{KE}$ & $\mathrm{O} 1$ & $\mathrm{X}$ & $\mathrm{O} 2$ & $\mathrm{O} 3$ \\
\cline { 2 - 6 } $\mathrm{R}$ & $\mathrm{KK}$ & $\mathrm{O} 1$ & - & $\mathrm{O} 2$ & $\mathrm{O} 3$ \\
\hline
\end{tabular}

Keterangan:

$\mathrm{R}$

: Random Assignment

KE : Kelompok Eksperimen

KK : Kelompok Kontrol

O1 : Pretest

O2 : Posttest

O3 : Follow-up

$\mathrm{X} \quad$ : Pelatihan Asertivitas

: Tanpa Perlakuan

\section{Subjek Penelitian}

Subjek dalam penelitian ini adalah 16 orang suami atau istri yang tinggal dalam keluarga luas dengan kriteria: Pendidikan minimal SMA, usia pernikahan kurang dari enam tahun (Dirjen Bimas Islam dan Urusan Haji Kementrian Agama mengatakan bahwa kasus perceraian untuk usia pernikahan enam tahun ke atas justru cukup rendah, Umar, 2010), belum pernah mengikuti pelatihan asertivitas dan memiliki skor rendah hingga sedang pada kemampuan pemecahan masalah interpersonal pada tahap screening.

Tahap Screening, subjek penelitian dikenakan skala KPMI A sejumlah 40 orang. Dari total subjek dipilih suami-istri yang memiliki kemampuan pemecahan masalah interpersonal yang rendah hingga 
sedang. Data screening subjek penelitian dapat dilihat pada tabel berikut:

Tabel 1

Data Hasil Screening Subjek Penelitian

\begin{tabular}{llll}
\hline Rentang Hasil & Kategori & Jumlah & \% \\
\hline $\mathrm{X}>117$ & Tinggi & - & 0 \\
$78 \leqslant \mathrm{X}<117$ & Sedang & 38 & 95 \\
$\mathrm{X}<78$ & Rendah & 2 & 5 \\
\hline
\end{tabular}

Dari 40 orang suami-istri yang memenuhi kriteria subjek penelitian, hanya 22 orang yang bersedia menjadi subjek penelitian. Kemudian 22 suami istri tersebut dilakukan randomisasi dengan sistem undian untuk memilik 20 prang suami-istri, dari 20 orang tersebut dikelompokkan ke dalam kelompok eksperimen dan kelompok kontrol secara random. Dari sepuluh undangan yang diberikan pada kelompok eksperimen, hanya delapan orang yang hadir, sehingga jumlah kelompok kontrol disesuaikan dengan kelompok eksperimen yaitu delapan orang.

\section{Metode Pengumpulan Data}

Pengumpulan data variabel tergantung dalam penelitian ini menggunakan metode skala, yaitu Skala Kemampuan Pemecahan Masalah Interpersonal $(\alpha=0,924)$. Skala tersebut disusun berdasarkan aspek-aspek kemampuan pemecahan masalah interpersonal menurut Levine (1998), yaitu; sikap mental (bagaimana seseorang dapat mengubah situasi dengan cara memikirkan apa yang seharusnya dilakukan oleh orang lain dan memfokuskan hanya pada apa yang terjadi, mencari situasi yang terbaik tanpa melanggar hak orang lain, bertanggungjawab pada perubahan yang dilakukan; cara bicara (mengatur kontak mata dengan baik, gaya bicara informal, tekanan suara proposional, berbicara yang mudah dimengerti oleh pendengar, dimulai dengan mengungkapkan perasaan tentang situasi, sopan seperti dengan kata “tolong, bisakah, jika tidak keberatan" dan lainlain, humor, dan ketenangan emosi); mediasi permasalahan pihak lain (tidak menghakimi atau tidak memilih benar dan salah, menghindari 
prasangka, tidak mengarahkan, mendorong kedua belah pihak pada solusi yang realistis, memberi kesempatan kedua belah pihak untuk "terbuka", atau mengekspresikan kemarahan, untuk melepaskan frustrasinya, menjadi lebih menerima untuk negosiasi, melihat dari berbagai sudut pandang).

\section{Teknik Analisis Data}

Uji hipotesis menggunakan Mann Whitney $U$ Test dan analisis Wilcoxon.

\section{HASIL DAN PEMBAHASAN}

\section{Uji Hipotesis}

Data yang digunakan sebagai dasar hipotesis yaitu data yang diperoleh dari hasil pretest, posttest dan follow-up data kemampuan pemecahan masalah interpersonal pada kelompok kontrol dan kelompok eksperimen. Mean rank pada kelompok kontrol untuk pretest adalah 8,00 untuk data posttest adalah sebesar 5,12, dan data follow-up sebesar 4,62. Sedangkan mean rank pretest untuk kelompok eksperimen adalah sebesar 9,00, mean rank posttest sebesar 11,88, dan mean rank follow-up sebesar 12,38.

Dari hasil tersebut dapat disimpulkan bahwa sebelum pemberian pelatihan asertivitas pada kelompok eksperimen nilai mean ranknya hampir sama dengan nilai mean rank kelompok kontrol, setelah diberikan pelatihan asertivitas nilai mean posttestnya mengalami kenaikan, dan setelah dilakukan pengukuran ulang dua minggu setelah pelatihan nilai mean rank kembali menunjukkan peningkatan dibandingkan mean rank posttest. Pada kelompok kontrol nilai mean rank pretest hampir sama dengan kelompok eksperimen, kemudian pada saat posttest mengalami penurunan, dan pada pengukuran ulang dua minggu setelah pelatihan kembali menunjukkan penurunan.

Untuk menguji hipotesis dilakukan uji beda menggunakan teknik Mann-Whitney $U$ Test dengan melihat selisih antara skor pretest dan posttest. Hasil uji beda skor pretest dengan posttest, gained skore menunjukkan koefisien $\mathrm{Z}$ sebesar $-2,596$ dengan $\mathrm{p}<0,005$. Hal ini menunjukkan bahwa ada perbedaan kemampuan pemecahan masalah 
interpersonal antara $\mathrm{KE}$ dan $\mathrm{KK}$ sebelum dan sesudah perlakuan (pelatihan asertivitas), dimana KE mengalami peningkatan kemampuan pemecahan masalah interpersonal (mean rank=12,00) dibandingkan dengan KK (mean rank= 5,00). Kemudian hasil uji beda skor posttest dan skor follow-up pada kelompok eksperimen menunjukkan koefisien Z sebesar $-2,373 \mathrm{p}<0,05$. Hal ini menunjukkan bahwa ada perbedaan kemampuan pemecahan masalah interpersonal antara KE dengan KK pada fase follow-up, dimana mean rank KE lebih tinggi $(11,31)$ dibandingkan mean rank KK $(5,69)$. Hal ini menunjukkan bahwa pelatihan asertivitas memiliki pengaruh yang berarti terhadap peningkatan kemampuan pemecahan masalah interpersonal.

Untuk mengetahui pengaruh pelatihan asertivitas terhadap kemampuan pemecahan masalah interpersonal, dilakukan pengujian terhadap skor pretest dan posttest pada KE melalui Wilcoxon test. Hasil analisis Wilcoxon terhadap skor pretest dan skor posttest pada $\mathrm{KE}$ menunjukkan koefien $\mathrm{Z}$ sebesar $-2,527 \mathrm{p}<0,05$, hal ini menunjukkan bahwa terdapat perbedaan kemampuan pemecahan masalah interpersonal pada kelompok $\mathrm{KE}$ antara sebelum dan setelah perlakuan (pelatihan asertivitas). Skor mean posttest $(117,250)$ lebih tinggi dibandingkan dengan skor mean pretest $(101,500)$. Hal ini berarti terjadi peningkatan kemampuan pemecahan masalah interpersonal pada KE setelah diberikan pelatihan asertivitas. Kemudian, hasil analisis Wilcoxon terhadap skor posttest dan skor follow-up menunjukkan koefisien $\mathrm{Z}$ sebesar $-2,103 \mathrm{p}<0,005$, dimana skor mean folow-up $(123,875)$ lebih tinggi dibandingkan dengan skor mean posttest (117,250). Hal ini berarti bahawa pelatihan asertivitas memberikan pengaruh yang berarti terhadap peningkatan kemampuan pemecahan masalah interpersonal pada suami atau istri dalam keluarga luas.

Dari hasil analisis di atas dapat disimpulkan bahwa suami atau istri yang mendapatkan pelatihan asertivitas mengalami peningkatan kemampuan pemecahan masalah interpersonal dibandingkan suamiistri yang tidak mendapatkan pelatihan asertivitas dan pengaruh pelatihan tersebut sangat berarti terhadap peningkatan kemampuan pemecahan masala interpersonal pada suami atau istri tersebut. Hal 
ini menunjukkan bahwa hipotesis yang diajukan yaitu suami atau istri yang mendapatkan pelatihan asertivitas mengalami peningkatan kemampuan pemecahan masalah interpersonal dibandingkan dengan suami atau istri yang tidak mendapatkn pelatihan asertivitas dapat diterima.

\section{Pembahasan}

Hasil analisis data menunjukkan bahwa hipotesis yang diajukan dapat diterima. Suami atau istri yang mendapatkan pelatihan asertivitas mengalami peningkatan kemampuan pemecahan masalah dibandingkan dengan suami atau istri yang tidak mendapatkan pelatihan asertivitas. Hal ini sesuia dengan hasil penelitian Farida yang menemukan bahwa pelatihan asertivitas sangat efektif untuk meningkatkan kemampuan pemecahan masalah. ${ }^{31}$

Cawood menambahkan bahwa setelah mendapatkan pelatihan asertivitas suami atau istri mampu untuk mengatasi atau memecahkan masalah secara nyata karena suami atau istri menjadi fokus terhadap persoalan dan proses yang ada saat itu, tidak dihambat oleh ketakutan-ketakutan akan masa lalu atau yang akan datang, hal ini berarti bahwa memiliki keberanian bertindak yang merupakan indikasi dari kemampuan pemecahan masalah interpersonal pada aspek mental. ${ }^{32}$

Pelatihan asertivitas pada suami atau istri dapat berhubungan dengan orang lain dengan konflik, kekhawatiran dan penolakan yang lebih sedikit seperti halnya yang sering terjadi dalam keluarga luas. ${ }^{33}$ Levine menambahkan, perlakuan yang sesuai untuk mengembangkan pemecahan masalah interpersonal adalah pelatihan asertivitas karena pelatihan asertivitas mengajarkan keberanian untuk menolak, keberanian untuk memberi perhatian, keberanian untuk menyetujui suatu gagasan, keberanian untuk meminta dengan mempertimbangkan hak-hak orang lain, hal tersebut merupakan

${ }^{31}$ Farida. Efektivitas pelatihan asertivitas,

${ }^{32}$ Cawood. Assertirtiveness for managers. Learning effective skills for managing people. Bussiness series. 2nd edition. (North Vancour, British Columbia: International Self - counsil Press Ltd. 1987).

${ }^{33}$ Corey. Principle-centered leadership, 
indikasi dari aspek kemampuan pemecahan masalah interpersonal pada aspek sikap mental. Dalam pelatihan tersebut juga diajarkan cara bicara dengan melibatkan kontak mata, suara yang proporsional, isyarat nonverbal, dan merespon dengan tepat tanpa menyakiti orang lain, hal tersebut juga merupakan indikasi kemampuan pemecahan masalah interpersonal pada aspek cara bicara. ${ }^{34}$

Townsend menambahkan, berperilaku asertif pada hampir semua situasi, membuat orang lain merasa respek, senang bekerjasama dengan individu yang bersangkutan. ${ }^{35}$ Perilaku asertif akan muncul pada saat suami atau istri melakukan hubungan interpersonal dengan orang tua atau mertua dan anggota keluarga luas lainnya. Dalam hubungan tersebut pihak yang satu merasa nyaman danpihak yang lain juga merasa nyaman. Nyaman dengan dirinya ditunjukkan dengan tidak terllau berlebihan dengan emosinya, memiliki toleransi, menghargai diri dan kemampuan untuk menghadapi dan menyelesaikan masalah interpersonal. Pernyataan tersebut di atas didukung oleh pernyataan NM pada fase follow-up serikut:

"Saya bisa lebih tegas, lebih tenang, lebih bisa menentukan pilihan, lebih bisa menjadi orang yang hangat"

Emosi yang tenang akan tercermin dari cara bicara suami-istri, toleransi tercermin dari sikap tidak menghakimi (mediasi) dan mencari solusi yang terbaik tanpa melanggar hak orang lain (sikap mental). Cara bicara, mediasi, dan sikap mental merupakan aspekaspek kemampuan pemecahan masalah interpersonal menurut Levine. Nunally \& Hawari menambahkan, suami atau istri yang asertif adalah yang memiliki daya tahan yang kuat, menghargai diri, dapat mengeskpersikan diri, menerima umpan balik, menyampaikan kritik serta dapat mengatasi masalah interpersonal dan konflik yang terjadi dalam keluarga luas dengan baik. ${ }^{36}$

${ }^{34}$ Levine. Effective problem solving,

35 Townend. Develoving assertiveness. (London: Routledge. 1991).

${ }^{36}$ Marini \& Andriani. Perbedaan Tingkat Asertivitas Remaja Ditinjau dari Pola Asuh Orang Tua. Psikologia, Vol.1(2),45-56. 2005. 
Melalui sesi "Membangun kesetaraan" suami atau istri memahami bagaimana cara membangun kesetaraan hubungan, sehingga meningkat kemampuan pemecahan masalah interpersonal pada aspek "sikap mental" dan aspek "mediasi permasalahan pihak lain”. Hal ini sesuai dengan pendapat Kelly, dkk bahwa suami atau istri yang mampu membangun kesetaraan terlihat lebih menyenangkan, lebih bersahabat, lebih mampu beradaptasi dan lebih hangat sehingga sedikit sekali kemungkinan berperang satu sama lain dalam percakapan. ${ }^{37}$ Posisi yang setara dengan orang lain membuat suami atau istri dan anggota lain dalam keluarga luas tidak merasa terancam posisinya, merasa nyaman, dan mampu membuka kemungkinan negosiasi saat menghadapi perselisihan untuk mencari jalan keluar. ${ }^{38}$

Pendapat di atas didukung oleh penelitan Iowa State University menemukan bahwa suami atau istri yang mencapai kesetaraan dalam hubungan menunjukkan memampuan adaptasi yang lebih dari cukup ketika menghadapi permasalahan. Kemampuan beradaptasi merupakan bagian dari sikap mental yang merupakan salah satu aspek kemampuan pemecahan masalah interpersonal. ${ }^{39} \mathrm{Hal}$ ini sesuai dengan pendapat DTH pada fase follow-up berikut:

"Saya baru tahu cara membangun kesetaraan hubungan bahwa yang berlebihan dalam suatu hal harus menurunkan sedikit dan yang memiliki kekurangan harus berusaha menaikkannya sedikit, jadi bisa sejajar, tidak ada pihak yang terkalahkan, ini pedoman saya untuk mencari solusi ketika ada masalah di antara orang-orang terdekat saya, khususnya antara saya dan istri semoga tidak lagi mementingkan ego masing-masing. Selain itu sekarang saya benar-benar merasa mampu memimpin keluarga karena saya mampu untuk tegas, lebih berani menentukan keputusan.”

${ }^{37}$ Teh, dkk. Does assertiveness and friendliness affect a person's satisfaction with social support?. Anima. Indonesian Psychology Journal. Vol. 21, No. 3, 2006, h. 219 - 228.

${ }^{38}$ Tim OBM. Pelatihan OBM kecakapan belajar UI: belajar di perguruan tinggi, halhal dasar belajar. (Jakarta: Universitas Indonesia. 2008).

39 Iowa State University. Family resiliency, building strenghts to meet life's challenges. (Iowa State University. 1995). 
Dari sesi “Express Yourself!" dan "Roleplay", suami atau istri mampu mengekspresikan diri berupa kemampuan untuk kurang setuju, menunjukkan amarah, memperlihatkan kasih sayang atau persahabatan, mengakui rasa takut atau cemas, bersikap spontan dan belajar untuk merespon hinaan, tekanan, dan cemoohan dengan cara yang tepat yaitu asertif. Sesi ini bertujuan untuk meningkatkan kemampuan pemecahan masalah interpersonal dari aspek "cara bicara" dan "mediasi permasalahan pihak lain". Hasil penelitian longitudinal yang dilakukan oleh Gottman, dkk menunjukkan bahwa pengungkapan perasaan positif (seperti humor dan kontak fisik yang positif) merupakan cara yang tepat untuk mengatasi konflik. ${ }^{40}$ Sebaliknya, suami atau sitri yang tidak asertif menggunakan kecaman, hinaan, dan egois dapat membawa ke permasalahan antara suami, istri dan anggota lain dalam keluarga luas seperti perselisiahan, perpisahan, bahkan perceraian. ${ }^{41}$

Permasalahan dapat meningkat karena suami atau istri merasa tidak mampu mengekspresikan perasaan secara langsung. Masalah interpersonal dapat dipecahkan dengan memberi perhatian kepada perasaan individu lain dalam keluarga luas seperti mertua atau orang tua, saudara kandung atau saudara ipar dan anggota keluarga lainnya. Perasaan seperti kemarahan yang tidak tepat tidak akan terselesaikan ketika perasaan tersebut tidak diekspresikan. Suami atau istri tersebut memungkinkan akan mengalami ledakan emosi di belakangan. ${ }^{42}$

Kemudian Hoof menyatakan bahwa, bahasa non verbal berupa senyuman berfungsi untuk menghindari permusuhan dan memelihara hubungan, ekspresi senyum akan mempertahankan atau bahkan meningkatkan interaksi antar suami-istri dan dengan anggota lain atau meningkatkan hubungan interpersonal dalam keluarga luas. Hal ini dikarenakan tersenyum merupakan isyarat keramahan, dapat menghindari permusuhan, membuat situasi yang menekan lebih

40 Gottman, dkk. Predicting marital happiness and stability from newlywed interaction. Journal af marriage and the family. Vol. 60, 1998. h. $5-22$.

${ }^{41}$ Gottman \& Notarius. Decase review: observing marrital interaction. Journal of marriage and the family. Vol. 62, 1998, h. 927 -947.

${ }^{42}$ Gustavi \& Colonna. Unit pembelajaran QU-2.4 hubungan antar pribadi. Edisi: A/ Revisi: 2 14/11/2007. Asosiasi politeknik Indonesia (ASPI). 2007. 
menyenangkan dan memelihara hubungan persahabatan, tersenyum juga berarti ekspresi simpati, memberi keyakinan atau ketentraman. ${ }^{43}$

Pendapat di atas didukung oleh pernyataan beberapa subjek penlitian pada fae follow-up berikut:

MKY mengatakan:

"Saya merasa lebih bebas (plong) terutama menghadapi mertua, lebih apa adanya sekarang, kalau dulu sering tidak berani mengutarakan ide, usul, dan pendapat saya"

Kemudian dikuatkan oleh SL:

"Saya bisa asertif memberi perhatian pada suami, biasanya saya malas seperti itu, hubungan kita terasa lebih dekat. Saya senang melihat perubahan positif suami saya, insyaAllah kehidupan saya akan lebih baik."

Kemudian Msy mengatakan:

"Banyak sekali ternyata manfaatnya, saya lebih leluasa untuk mendiskusikan apa saja kepada suami, dan suami saya sudah belajar bagaimana mengkomunikasikan saya dengan keluarganya.”

Dan didukung oleh pendapat Rsy sebagai berikut:

"Banyak perubahan yang kami alami, banyak hal yang bisa kami bahas bersama, hubungan kami seperti tidak lagi tersekat."

Dari pembahasan di atas dapat disimpulkan bahwa pelatihan asertivitas dapat meningkatkan kemampuan pemecahan masalah interpersonal suami atau istri dalam keluarga luas yang ditandai dengan meningkatnya sikap mental, cara bicara dan kemampuan memediasi permasalahan pihak lain dalam keluarga luas.

\section{KESIMPULAN}

Berdasarkan hasil penelitian dan pembahasan dapat disimpulkan bahwa suami atau istri yang mendapatkan pelatihan asetivitas memiliki kemampuan pemecahan masalah interpersonal yang lebih tinggi dari pada suami atau istri yang tidak mendapatkan pelatihan

${ }^{43}$ Hasanat. Ekspresi senyum untuk meningkatkan hubungan interpersonal. Buletin Psikologi, Tahun IV, Nomor 1, Agustus 1996. 
asertivitas. Melalui sesi-sesi pelatihan "Membangun kesetaraan", "Be Yourself", "Express Yourself" dan "Role Play" dapat meningkatkan kemampuan pemecahan masalah interpersonal yang dapat dilihat dari sikap mental yang positif, cara bicara yang tepat, dan kemampuan memediasi permasalahan pihak lain.

\section{Daftar Pustaka}

Anderson B.F. The complete thinker. A hand book if techniques for creative and critical problem solving. Englewood Clift, New Jersey: Prentice-Hall Inc. 1980.

Bimo Walgito. Psikologi Sosial. Yogyakarta: Andi Offset. 2003.

Gordon H Bower. Theories Of Learning, Englewood Cliff : Prentice Hall, 1981.

Burley-Allen. Managing assertively-how to improve your people skills. New York: John Wiley and Son.Inc. 1983.

Cawood. Assertirtiveness for managers. Learning effective skills for managing people. Bussiness series. 2nd edition. North Vancour, British Columbia: International Self - counsil Press Ltd. 1987.

Covey. Principle-centered leadership. Simon \& Schuster, London. Buletin Psikologi. Tahun IX, No. 2, Desember 2001. 1990.

Daromi, F. Membina keluarga dengan mengenali bibit. http://arsinfo.co.cc/2010//11/.html. 2010.

Farida. Efektivitas pelatihan asertivitas untuk meningkatkan kemampuan pemecahan masalah pada siswa. Tesis. Yogyakarta: Program Pascasarjana Universitas Gadjah Mada. 2006.

Gottman \& Notarius. Decase review: observing marrital interaction. Journal of marriage and the family. Vol. 62, 2000.

Gottman, dkk. Predicting marital happiness and stability from newlywed interaction. Journal af marriage and the family. Vol. 60, 1998. 
Gustavi \& Colonna. Unit pembelajaran QU-2.4 hubungan antar pribadi. Edisi: A/ Revisi: 2 14/11/2007. Asosiasi politeknik Indonesia (ASPI). 2007.

Hadjono. Perlakuan salah di dalam keluarga. Laporan Seminar. Fakultas Kedokteran Universitas Udayana Denpasar. 1985.

Hasanat. Ekspresi senyum untuk meningkatkan hubungan interpersonal. Buletin Psikologi, Tahun IV, Nomor 1, Agustus 1996.

Iowa State University. Family resiliency, building strenghts to meet life's challenges. Iowa State University. 1995.

Ismayudha, Y. Pengaruh pelatihan asertif terhadap kecemasan sosial pada remaja. Skripsi. Yogyakarta: Universitas Gadjah Mada. 1995.

Kanfer, F. H. \& Goldstein, A. P. Helping people change. New York: Pergumon press. 1986.

Kelley, Harold H. Attribution Theory in Social Psychology. Nebraska Symposium on Motivation, Vol 15. 1967.

Marini \& Andriani. Perbedaan Tingkat Asertivitas Remaja Ditinjau dari Pola Asuh Orang Tua. Psikologia, Vol.1(2), 2005.

Myers \&Myers. The dynamic of human communication: A Laboratory Approach. Sixt Editon. Singapore: Mc.Graw Hill.Inc. 1992.

Rees, S \& Graham, R.S. Assertion training: how to be who you really are. (Strategies for mental health). New York : A Tavistock/Routledge Publication. 1991.

Solikah. Konflik interpersonal antara anggota keluarga besar. Skripsi. Tidak diterbitkan: Fakultas Psikologi Universitas Muhammadiyah Surakarta. 2010.

Soresi, S., Nota, L., dan Robert,W. Relation of Type and Amount of Training to Career Counseling Self-Efficacy in Italy. The Career Development Quarterly, Vol. 52, No. 3, ProQuest Research Library, 2004. 
Spivack, Platt, \& Shure. The problem-solving approach to solving real life problem. San Franssisco: Jossey-Bass. 1976.

Syukri \& Zulkarnain. Asertivitas dan kreativitas pada karyawan yang bekerja di multi level marketing. Jurnal Psikologia. Vol. I, No.2, 2005.

Teh, dkk. Does assertiveness and friendliness affect a person's satisfaction with social support?. Anima.Indonesian Psychology Journal. Vol. 21, No. 3, 2006.

Thanan. Risalah pergerakan pemuda Islam. Jakarta: Visi Media. 2001.

Tim OBM. Pelatihan OBM kecakapan belajar UI: belajar di perguruan tinggi, hal-hal dasar belajar. Jakarta: Universitas Indonesia. 2008.

Townend. Develoving assertiveness. London: Routledge. 1991.

Umar, N. Perceraian Usia Muda. POSMETRO. 14 September 2010.

Uyun. Pelatihan asertivitas untuk meningkatkan ketahanan istri. Fenomena: Vol. 2 No. 1 Maret 2004.

Walker, et.all. Clinical procedures for behavior therapy. New Jersey: Prentice-Hall.Inc. Englewood Cliffs. 1981. 